\title{
Beetles that live with ants (Coleoptera, Carabidae, Pseudomorphini): A remarkable new genus and species from Guyane (French Guiana), Guyanemorpha spectabilis gen. $\mathbf{n}$., sp. $\mathbf{n}$.
}

\author{
Terry L. Erwin ${ }^{1, \dagger}$ \\ I Hyper-diversity Group, Department of Entomology, MRC-187, National Museum of Natural History, \\ Smithsonian Institution, Washington, P.O. Box 37012, DC 20013-7012, USA \\ † http://zoobank.org/A7923396-E5AB-4C31-842A-12B8D8C0F315 \\ Corresponding author: Terry L. Erwin (erwint@si.edu)
}

Academic editor: L. Penev | Received 24 September 2013 | Accepted 24 November 2013 | Published 3 December 2013

http://zoobank.org/288635AE-126C-4EOF-8451-5443AAEEE18D

Citation: Erwin TL (2013) Beetles that live with ants (Coleoptera, Carabidae, Pseudomorphini): A remarkable new genus and species from Guyane (French Guiana), Guyanemorpha spectabilis gen. n., sp. n. ZooKeys 358: 11-23. doi: $10.3897 /$ zookeys.358.6298

\begin{abstract}
Among the extensive collections currently being made in Guyane (French Guiana), adults of a large and colorful species of pseudomorphine were encountered. The adults present, for the first time in the Western Hemisphere, elytra with a marked color pattern, and in addition a size considerably beyond that of the rest of the members of all other known genera in the Western Hemisphere. Both of these attributes, however, are well known in the Australian pseudomorphine fauna. This new species is described and illustrated and a revised key to the Western Hemisphere genera is included. The type locality of Guyanemorpha spectabilis gen. n., sp. n. is Guyane, Risquetout, PK20, $4.916^{\circ} \mathrm{N}, 52.516^{\circ} \mathrm{W}, 12 \mathrm{~m}$ altitude.
\end{abstract}

\section{Resumen}

Entre las colecciones extensivas que actualmente se están conduciendo en Guyane (Guyana Francesa), los adultos de las especies grandes y coloridas de pseudomorfinos fueron encontrados. Los adultos presentan, por primera vez en el hemisferio occidental, élitros con un patrón colorido marcado, además de un tamańo mucho mayor que el resto de los miembros de todos los otros géneros en el hemisferio occidental. Ambos atributos, sin embargo, se conocen bastante bien en la fauna pseudomorfina de Australia. Esta nueva especie se describe e ilustra y una clave revisada para los géneros del hemisferio occidental se incluye. La localidad tipo de Guyanemorpha spectabilis gen. n., sp. n. es Guyane, Risquetout, PK20, $4.916^{\circ} \mathrm{N}$, $52.516^{\circ} \mathrm{W}$, altitud de $12 \mathrm{~m}$.

Copyright Terry L. Erwin. This is an open access article distributed under the terms of the Creative Commons Attribution License 3.0 (CC-BY), which permits unrestricted use, distribution, and reproduction in any medium, provided the original author and source are credited. 


\section{Keywords}

False-form beetles, identification key, distribution, male genitalia, female ovipositor, Hymenoptera: Formicidae

\section{Palabras clave}

Carábidos atípicos, clave de identificación, distribución, genitalia de macho, ovipositor de hembra, Hymenoptera: Formicidae

\section{Introduction}

Surprising taxa of Carabidae continue to surface as collections from remote places and new habitats are explored (e.g., Erwin 2000, 2004; Erwin and Geraci 2008). Another such taxon has been discovered in various parts of Guyane during ongoing biotic inventories in reserved areas of Guyane and exploration of that country's insect biodiversity by The Entomological Society Antilles-Guyane (SEAG) (cf. Erwin et al. 2012). The species is remarkable because the adults (Fig. 1) present, for the first time in the Western Hemisphere, elytra with a marked color pattern, and in addition a size considerably beyond that of the rest of members of the other known genera in the Western Hemisphere. Both of these attributes, however, are well known in the Australian pseudomorphine fauna (Baehr 1992, 1997) and it is likely a greater variety of color forms will be found in the future in South America.

\section{Specimens and methods}

Included in this study are a total of 4 specimens from other institutions and private collections (Appendix 1). "Methods and species concepts follow those previously described (Ball 1959; Erwin and Kavanaugh 1981; Kavanaugh and Erwin 1991). The species validation and diagnosis format follows as closely as possible that suggested in Erwin and Johnson (2000). Measurements of length (ABL, SBL) and width (TW) follow those of Ball (1972) and Kavanaugh (1979): ABL (apparent body length), measured from apex of labrum to apex of the abdomen; SBL (standardized body length), equals the sum of the lengths of the head (measured from apex of clypeus to a point on midline at level of the posterior edge of compound eyes), PL (pronotal length ), measured from apical to basal margin along midline, and LE (elytron length), measured from apex of scutellum to apex of the longer elytron; and TW (total width), measured across both elytra at their widest point with suture closed."

"Habitus and attribute images of the adult beetles portray most of the character states referred to in the key provided. Male and female genitalic presentations are standard for descriptive taxonomy of carabid beetles, and in this case are digital photoillustrations (Erwin 2011). The images of the adult and its parts were made with a Visionary Digital ${ }^{\mathrm{TM}}$ high resolution imaging system. Figure captions include an ADP number, which is a unique identification number for the specimen that was illustrated 
or imaged and links the specimen and associated illustrations and/or image to additional information in electronic databases at the NMNH."

"Geographical data are presented based on all known specimens of each species available at the time of manuscript preparation. Georeferences have been determined from locality information provided on specimen labels. Latitude and longitude are reported in decimal degrees. A distribution map is provided for the species [Fig. 5]. Here, an English vernacular name is proposed, as vernacular names are becoming increasingly needed in conservation and/or agricultural and forestry applications, as well as for the Encyclopedia of Life (www.eol.org)," (Erwin and Amundson in press).

\section{Accounts of taxa}

\section{Western Hemisphere genera of Pseudomorphini Newman 1842}

Guyanemorpha Erwin, gen. n. Guyane (French Guiana)

Manumorpha Erwin \& Geraci, 2008. Brazil, Ecuador, Guyane, Perú

Notopseudomorpha (Baehr, 1997). Middle and South America

Pseudomorpha (s. str.) Kirby, 1825. USA south to Argentina (incl. Caribbean islands)

Samiriamorpha Erwin \& Geraci, 2008. Perú

Tuxtlamorpha Erwin \& Geraci, 2008. México, Honduras

Yasunimorpha Erwin \& Geraci, 2008. Ecuador

\section{Key to the Western Hemisphere genera of Pseudomorphini Newman 1842}

1 Mouthparts not visible in dorsal aspect. Preocular lobe absent .....................2

1' Mouthparts visible in dorsal aspect. Preocular lobe present..........................3

2(1) Dorsal surface glabrous, markedly shiny... Notopseudomorpha (Baehr, 1997)

2' Dorsal surface finely setiferous, not shiny.

Samiriamorpha Erwin \& Geraci, 2008

3(1') Elytron with only scutellar and ombilicate setae; with elytra markedly tapered

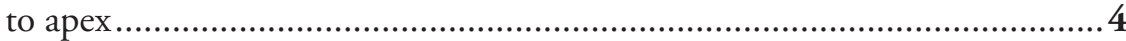

3' Elytron multisetiferous; body form rather broad and subdepressed with elytra not or barely tapered to broadly round apex ..............................................5

4(3') Body form narrow, somewhat cylindrical

Yasunimorpha Erwin \& Geraci, 2008

4' Body form very broad, not cylindrical.....................Guyanemorpha gen. n.

5(3) Dorsal surface with dense vestiture, of very long thick erect setae equal in length at least to basal 4 antennomeres, but no pubescence; body form subconvex, elytra tapered posteriorly...... Manumorpha Erwin \& Geraci, 2008

5' Dorsal surface with sparse or no long vestiture, longer setae equal in length only to at most basal 3 antennomeres, also usually with short pubescence; body form subconvex, elytra slightly tapered posteriorly or not....................6 
6(5) Major setae of dorsal surface erect or slightly curved posteriorly....

Pseudomorpha Kirby, 1825

6' Major setae of elytra posteriorly directed and markedly decumbent

Tuxtlamorpha Erwin \& Geraci, 2008

\section{Pseudomorphini Newman, 1842 \\ http://species-id.net/wiki/Pseudomorphini}

Pseudomorphini Newman, 1842:365 (as Pseudomorphites)

Proposed english vernacular name. False-form beetles.

Taxonomy. Stable at the generic level.

Classification. According to Ober and Maddison (2008), Pseudomorphini appears as a branch of the higher Carabidae and associated with Graphipterini and Orthogonini; according to Erwin and Geraci (2008), the adelphotaxon is the tribe Orthogonini. All three tribes are associated in some way with ants or termites. Male genitalia of pseudomorphines have a bonnet-shaped phallobase as in the lebiomorphs, yet their accompanying parameres are large and nearly symmetrical (and in some species the parameres are sparsely setiferous), as in some primitive lineages of the family. Many known lineages of Pseudomorphini have been so highly selected for life with ants (and possibly termites) that external structures do not help much in discovering more normal carabid relatives (cf. Erwin and Amundson, in press).

Taxonomy references. Baehr (1992, 1997); Erwin and Amundson (in press); Erwin and Geraci (2008); Notman (1925), Ogueta (1967).

Larval references. Erwin (1981); Lenko (1972); Liebherr and Kavanaugh (1985), Moore (1964, 1974, 1983).

Guyanemorpha Erwin, gen. n.

http://zoobank.org/66A2E5B7-0831-4E1E-8AD2-ECE683F0AD8D

http://species-id.net/wiki/Guyanemorpha

Type species. Guyanemorpha spectabilis Erwin, sp. n.

Proposed english vernacular generic name. Guyane False-form beetles

Adelphotaxon. Probably Notopseudomorpha (Baehr, 1997) (see Erwin and Geraci 2008 for phylogeny).

Description. Head (Fig. 2) without supraorbital setigerous punctures, nor any accessory setae; frontal impressions absent. Labrum barely visible with anterior margin shallowly emarginate, quadrisetose; clypeus markedly wide, nearly obscured in dorsal aspect by protruding frons, with obtuse setiferous lateral corners. Eyes slightly convex; small gena with numerous stout setae. Antenna short, just reaching anterior coxa in repose; antennomeres 3-9 slightly wider than 1-3, and appearing slightly flattened. Mandible markedly flattened with a very short and acute apex; outer margin ventral of the scrobe without short 
stout setae. Maxillary palpi markedly short, 3-segmented, palpomeres slightly depressed, palpomere 3 truncate apically. Labial palpus with short bisetose palpomere 2; palpomere 3 markedly securiform and robust, its distal margin mostly membranous with sensory organs.

Prothorax. Pronotum (Fig. 1) much wider than head, transverse, with narrowly beaded margins; without a pair of setigerous punctures each side, apical, lateral and posterior margins with fringe of short stout setae; hind angles obtuse, broadly rounded. Prosternal process unisetiferous subapically, intercoxal process feebly beaded.

Pterothorax. Metepisternum elongate and markedly narrowed posteriorly, the outer margin about 2 times greater in length than the anterior margin, posterior margin about 0.2 times anterior margin.

Elytra. Elytron (Fig. 1) tapered, markedly narrower apically, width of elytra about equal to that of pronotum at widest point, apical margin truncate with evenly rounded humerus, interneurs and intervals effaced; parascutellar stria absent, scutellum hidden, parascutellar puncture present, marked; without fixed discal setae, surface glabrous. Lateral marginal (umbilical) series of 10 setae, arrayed throughout and widely spaced; lateral margin with fringe of short stout setae.

Hind wings. Macropterous. Venation (Fig. 3).

Legs. Short and depressed, femur posteriorly channeled for reception of tibia in repose; antennal comb notch very shallow; tibial spurs normal; anterior tarsi of male with tarsomeres 2-4 dilated slightly, ventrally each with two laterally placed rows of adhesive articulo-setae.

Abdomen. Abdominal sterna III-VII with patches of short setae and each of IVVII with a single row of erect ambulatory setae numbering 2 to 8 setae; V and VI in male each with dense row of yellowish robust setae separated medially.

Male genitalia (Fig. 4). Phallobase hooded with small orifice, dorsum not crested; phalloshaft arched throughout its length, diameter sub-rounded to somewhat depressed dorso-ventrally; phalloapex produced, sharp, rounded, markedly depressed dorso-ventrally; endophallus orifice elongate, endophallus with dense patches of microtrichia. Parameres (C) moderately short compared to those of genus Pseudomorpha, nearly equal in length, left slightly longer and much broader than right, each apically glabrous. Ring sclerite (E) normal for family.

Female ovipositor and genital tract (Fig. 1). Gonocoxite 2 falcate, base about as long as blade, latter relatively short, pointed distally; margins without ensiform setae; with short preapical nematiform seta.

\section{Guyanemorpha spectabilis Erwin, sp. n.}

http://zoobank.org/B86F564C-10FD-43CD-B257-DDE8425CF0D7

http://species-id.net/wiki/Guyanemorpha_spectabilis

Figures 1-5

Holotype. Guyane (French Guiana): Risquetout, PK20, $4.916^{\circ} \mathrm{N}, 52.516^{\circ} \mathrm{W}, 12 \mathrm{~m}$, 13 December 2010 (SEAG)(NMNH, held in trust, see below: ADP132101, female). Paratypes are listed below under other specimens examined. 

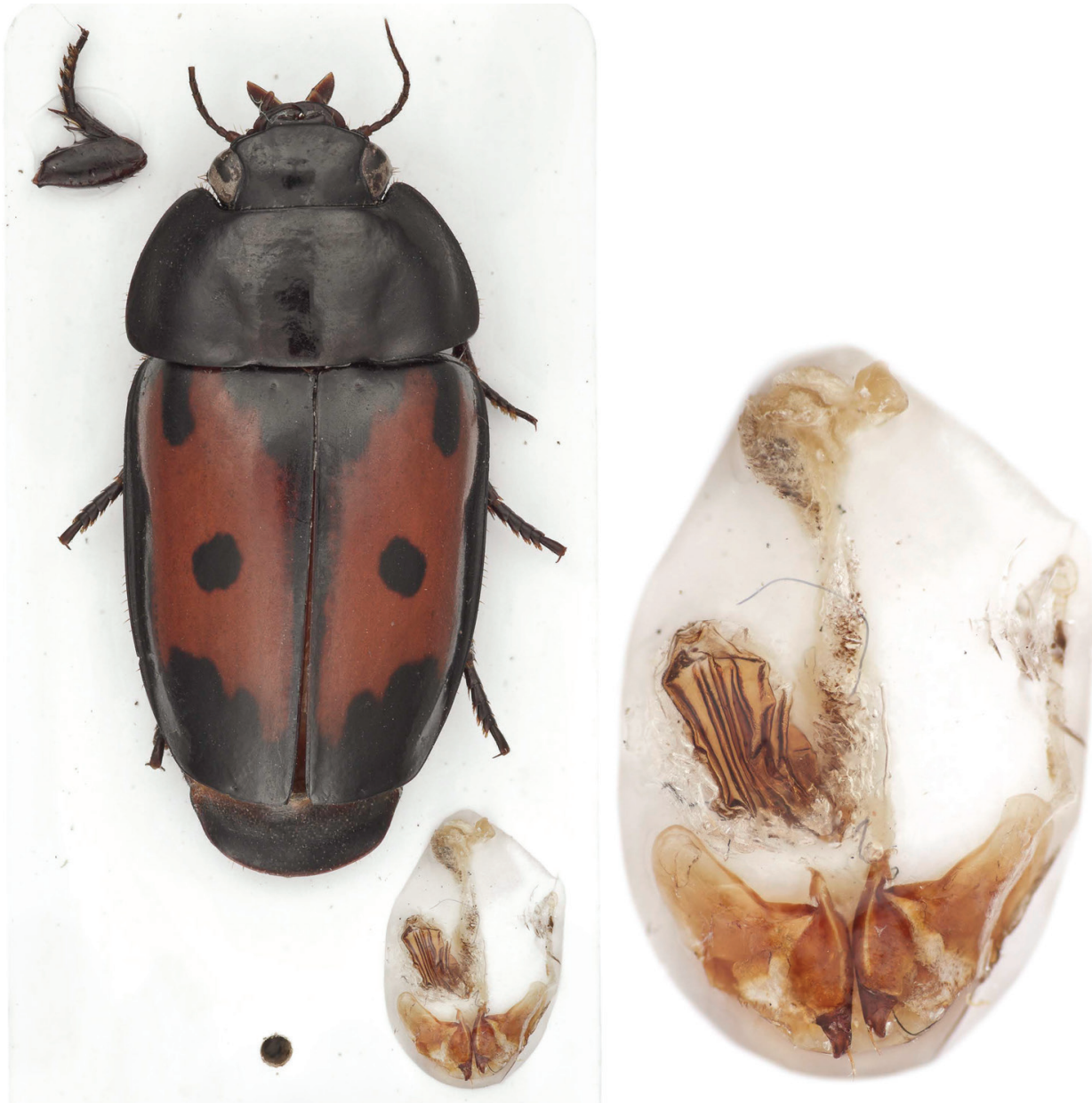

Figure I. Guyanemorpha spectabilis sp. n., female holotype, ADP132101; Risquetout, PK20, Guyane. Habitus and female genital tract glued to card, dorsal aspect, $A B L=13.2 \mathrm{~mm}$.

Derivation of specific epithet. The epithet "spectabilis" is a Latin adjective describing the very large and colorful beetle species.

Proposed english vernacular name. Spectacular Guyane False-form beetle.

Diagnosis. With the attributes of the genus as described above and color black and rufous with elytral spots (Fig. 1), color tone of head and pronotum uniform black; form broad and stout with tapered elytra; head with preapical lobe prominent but hidden in dorsal aspect beneath the frons, about $2 / 3$ the length of the anterior margin of eye; pronotum (Fig. 1) coequal at base to elytra across humeri; elytron markedly tapered from humerus to narrower truncated apex and without interneurs or intervals, surface glabrous except parascutellar seta and 8 ombilicate setae near lateral margin.

Description. (Figs 1, 2, 3, 4; Appendix 3). Size: Very large for a Western Hemisphere species, $\mathrm{ABL}=13.18$ to $13.51 \mathrm{~mm}, \mathrm{SBL}=11.05$ to $12.18 \mathrm{~mm}, \mathrm{TW}=6.36$ to $6.86 \mathrm{~mm}$. 


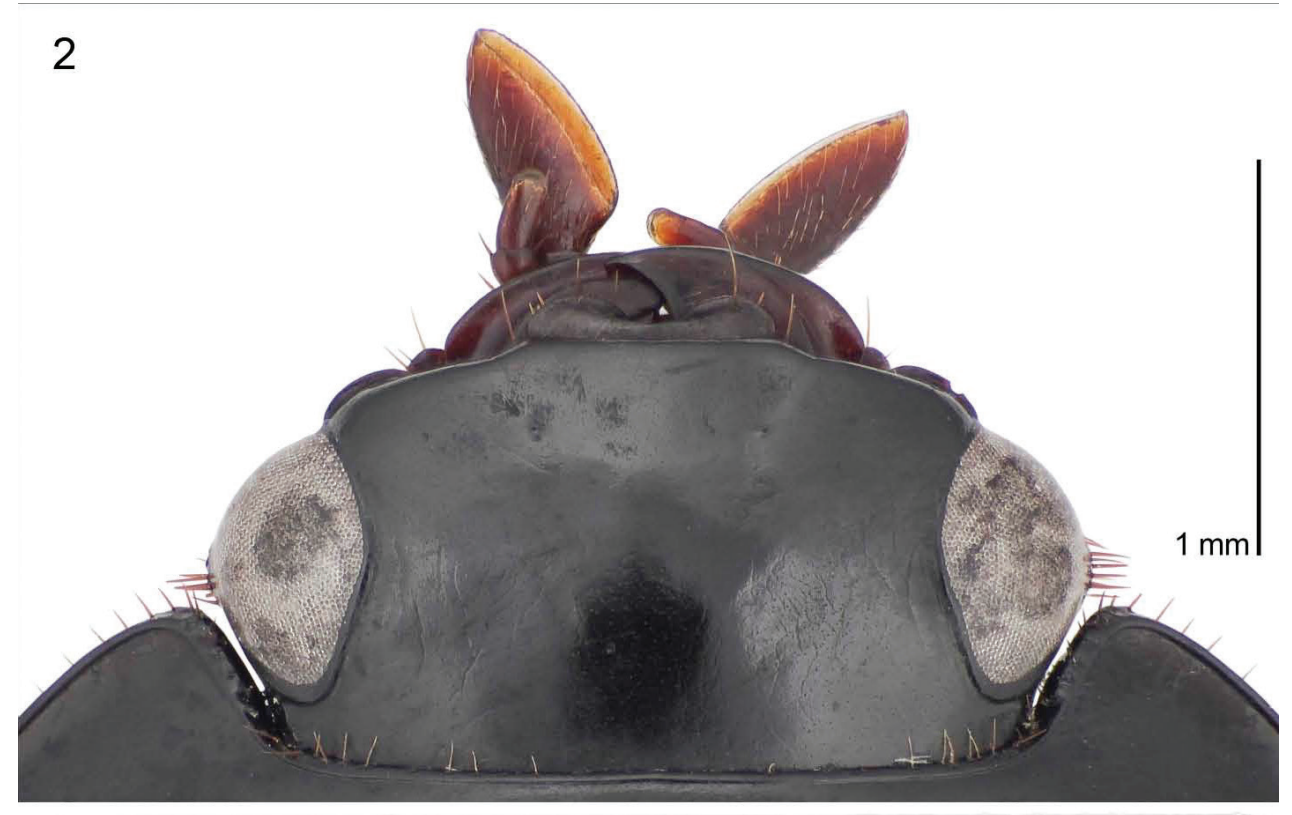

3

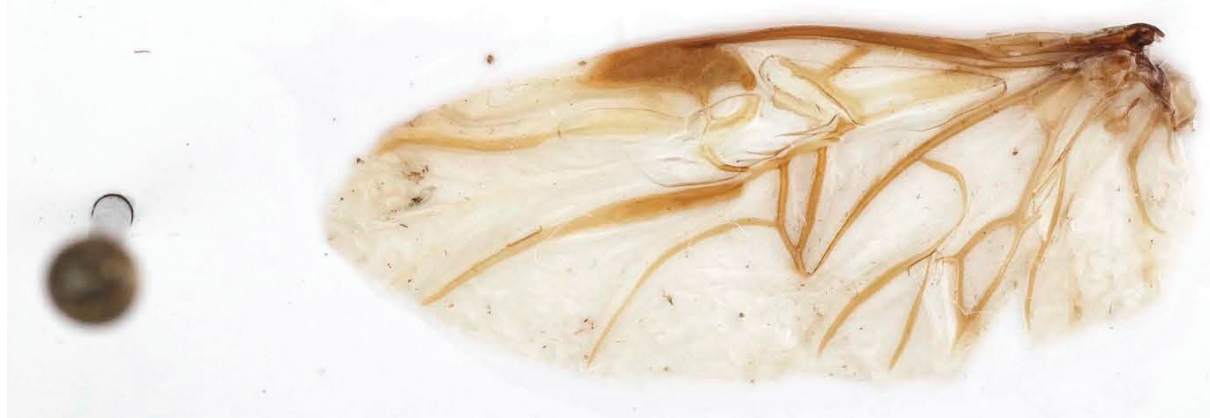

Figure 2-3. 2 Guyanemorpha spectabilis sp. n., female holotype, ADP132101; Risquetout, PK20, Guyane. Head, dorsal planar aspect 3 Guyanemorpha spectabilis sp. n., female paratype, ADP132105; Nouragues, Saut Pararé, Guyane. Left flight wing, dorsal aspect.

Preocular lobe-eye ratio (L/L): 0.49 to 0.54 . Pronotum ratio (L/W): 1.99 to 2.16. Pronotum ratio (W/L): 2.20 to 2.29. As described for genus above and the diagnosis.

Dispersal potential. These beetles are macropterous and have been recorded from flight intercept traps (FITs), hence fully capable of flight; they are likely swift and agile runners as other species in the Tribe. Accordingly, this species may be expected to be more broadly distributed across a wider geographical range than current records indicate.

Way of life. Adults of other pseudomorphines in the Western Hemisphere are found in ant nests and the surrounding vicinity and possibly in termite nests (Ogueta 1967); female adults of species of Pseudomorpha are ovoviviparous (Liebherr and Ka- 


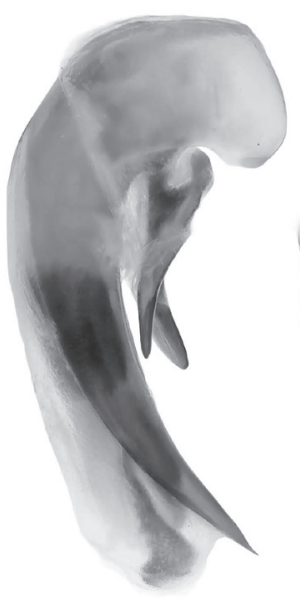

A

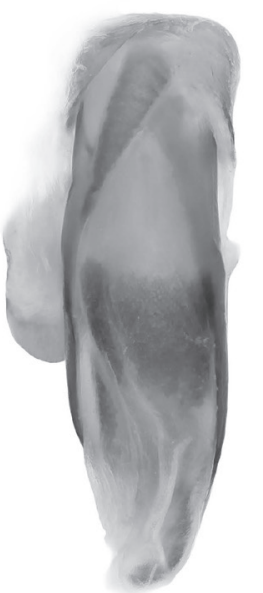

B

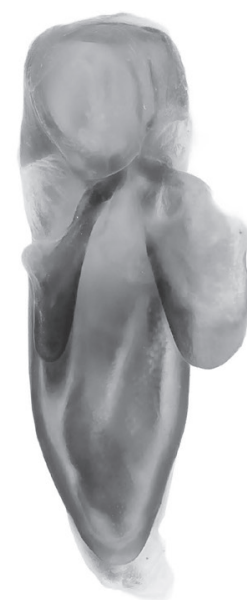

C

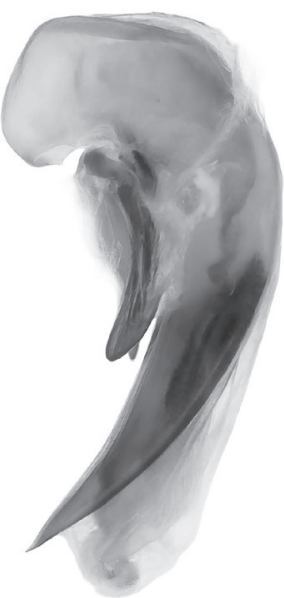

D

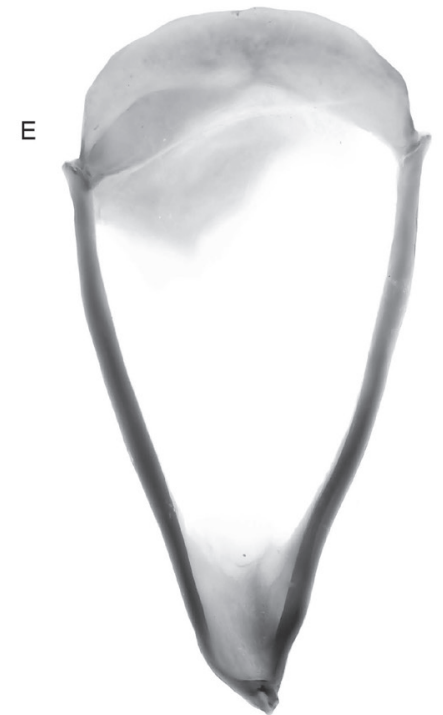

Figure 4. Guyanemorpha spectabilis sp. n., male paratype, ADP132103; Risquetout, PK20, Guyane. Male genitalia, median lobe and parameres labeled as in repose in male $\mathbf{A}$ ventral aspect $\mathbf{B}$ right lateral aspect $\mathbf{C}$ left lateral aspect $\mathbf{D}$ dorsal aspect.

vanaugh 1985); Pseudomorpha and Notopseudomorpha larvae are ant nest inquilines (Erwin 1981, Lenko 1972). Members of G. spectabilis occur at lowland rainforest sites and most likely live with ants. They have been found in July and December.

Other specimens examined. Guyane: Réserve Trésor, $4.610^{\circ} \mathrm{N}, 52.279^{\circ} \mathrm{W}$, 225m, 11 July 2009 (S. Brule)(BMNH, ADP124772, male paratype); Risquetout, PK20, $4.916^{\circ} \mathrm{N}, 52.516^{\circ} \mathrm{W}, 12 \mathrm{~m}, 13$ December 2010 (J.L. Giuglaris) (MNHP: ADP132103); Nouragues, Saut Pararé, $4.02^{\circ} \mathrm{N}, 52.41^{\circ} \mathrm{W}, 51 \mathrm{~m}, 14$ July 2010 (SEAG) (MNHP, ADP132105, female paratype). 


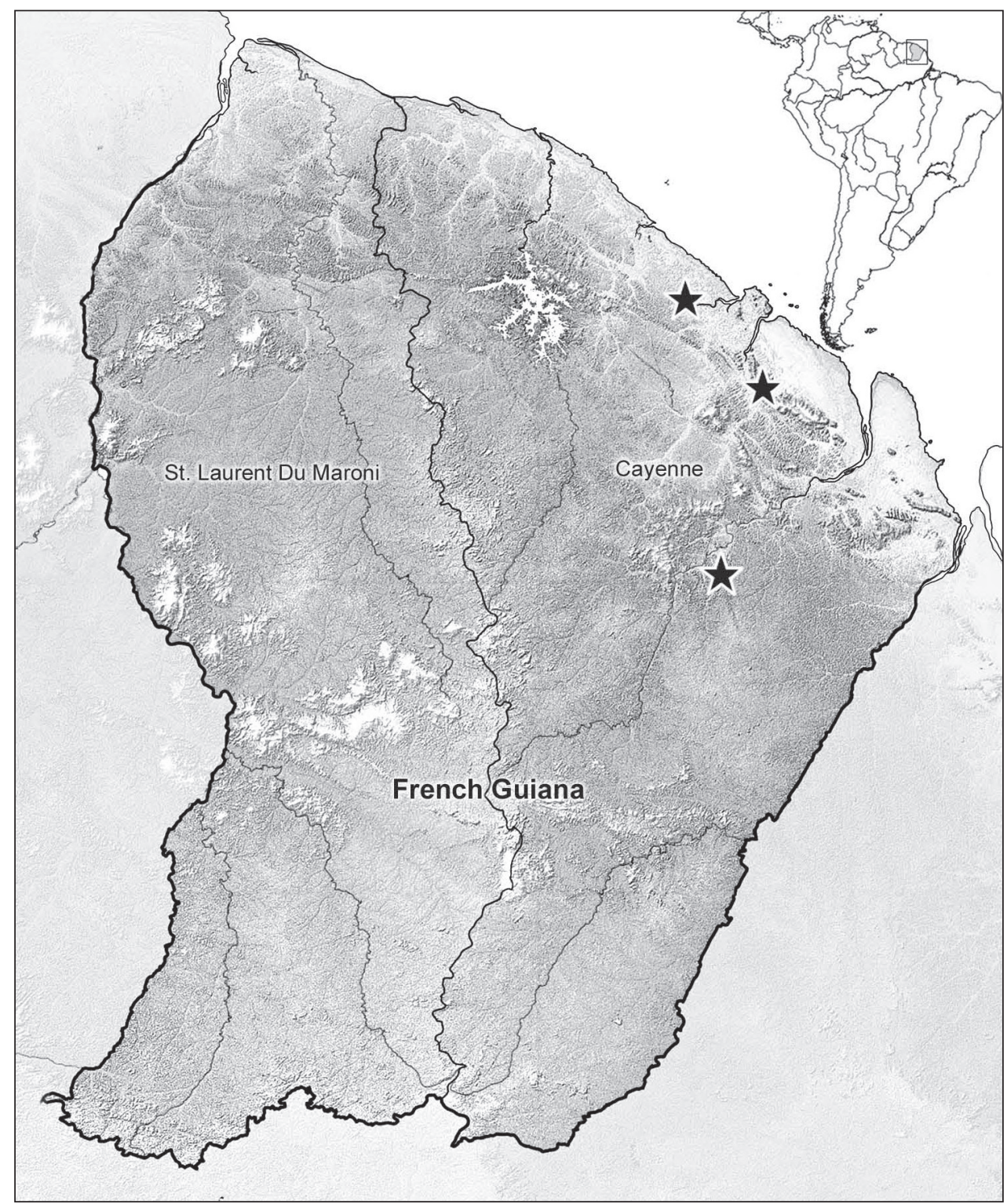

Figure 5. Distribution dot map for known localities of Guyanemorpha spectabilis sp. n.

Geographic distribution. (Fig. 5). This species is currently known only from Guyane.

Note. The holotype is currently held in trust at the National Museum of Natural History, Smithsonian Institution, Washington, DC until the planned Natural History Museum of Guyane is established, and at that time the specimen will be transferred there. See details of SEAG carabid collections in Erwin et al. 2012. 


\section{Concluding statement}

Adults of Guyanemorpha share attributes with those of both Notopseudomorpha (Baehr) and Yasunimorpha Erwin \& Geraci. This surprising large and colorful pseudomorphine came as a shock to the author, as all other species of the Tribe in the Western Hemisphere are quite dull fulvous, rufous, or black with no, or little, color contrast on the dorsal surface. Since little in the way of life information is available for the four specimens reported herein except seasonality of adult activity and lowland habitation, only speculation based on fogging samples in Perú and Ecuador can add much to this conclusion. "The pseudomorphines are a very interesting evolutionary off-shoot of the normal carabid morphotype in both form and function and are only just now beginning to be understood in North America. The fact that species of related genera in South America are living with arboreal ants will make learning about them far more difficult. Insecticidal fogging gets adults of these species, but only tearing apart arboreal Azteca ant nests while suspended in a tree will produce their larvae, and that is not for carabidologists faint of heart." Erwin and Amundson (in press).

\section{Acknowledgements}

In addition to the museum curators and collection managers noted in Appendix 1, we also extend hearty thanks to Charyn Micheli for the Resumen and friendly review of the manuscript, and Karolyn Darrow for the images and review of the Figure Captions (both of the Department of Entomology at the Smithsonian Institution).

\section{References}

Baehr M (1992) Revision of the Pseudomorphinae of the Australian region. 1. The previous genera Sphallomorpha Westwood and Silphomorpha Westwood. Taxonomy, phylogeny, zoogeography. (Insecta, Coleoptera, Carabidae). Spixiana, Supplement 18: 1-439.

Baehr M (1997) Revision of the Pseudomorphinae of the Australian region. 2. The genera Pseudomorpha Kirby, Adelotopus Hope, Cainogenion Notman, Paussotropus Waterhouse, and Cryptocephalomorpha Ritsema. Taxonomy, phylogeny, zoogeography. (Insecta, Coleoptera, Carabidae). Spixiana, Supplement 23: 1-508.

Ball GE (1959) A taxonomic study of the North American Licinini with notes on the Old World species of the Genus Diplocheila Brullé (Coleoptera). Memoirs of the American Entomological Society 16: iv + 1-258.

Ball GE (1972) Classification of the species of Harpalus subgenus Glanodes Casey (Carabidae: Coleoptera). The Coleopterists Bulletin 26: 179-204.

Erwin TL (1981) A synopsis of the immature stages of Pseudomorphini (Coleoptera: Carabidae) with notes on tribal affinities and behavior in relation to life with ants. The Coleopterists Bulletin 35(1): 53-68. 
Erwin TL (2000) A new genus and species of Lachnophorini and two new species of Lebiini from Costa Rica (Coleoptera: Carabidae). The Coleopterists Bulletin 54(3): 279-283. doi: 10.1649/0010-065X(2000)054[0279:ANGASO]2.0.CO;2

Erwin TL (2004) The Beetle Family Carabidae of Costa Rica and Panamá: Descriptions of four new genera and six new species with notes on their way of life (Insecta: Coleoptera). Zootaxa 537: 1-18.

Erwin TL (2011) Rainforest understory beetles of the Neotropics, Mizotrechus Bates 1872, a generic synopsis with descriptions of new species from Central America and northern South America (Coleoptera, Carabidae, Perigonini). ZooKeys 145: 79-128. doi: 10.3897/ zookeys. 145.2274

Erwin TL, Geraci CJ (2008) New genera of Western Hemisphere Pseudomorphini (Insecta: Coleoptera, Carabidae). In: Penev L, Erwin T, Assmann T (Eds) Back to the Roots and back to the future: towards a new synthesis between taxonomic, ecological, and biogeographical approaches in carabidology. Proceedings of the XIII European Carabidologists Meeting, Blagoevgrad, August 20-24, 2007. Pensoft Publishers, Sofia, Bulgaria, $77-100$.

Erwin TL, Johnson PJ (2000) Naming species, a new paradigm for crisis management in taxonomy: Rapid journal validation of scientific names enhanced with more complete descriptions on the internet. The Coleopterists Bulletin 54(3): 269-278. doi: 10.1649/0010-065X( 2000)054[0269:NSANPF]2.0.CO;2

Erwin TL, Micheli C, Hevel G (2012) Neotropical beetles of Guyane: Genera of the family Carabidae (Coleoptera) with notes on species richness currently known from the literature and recent collections. Le Coléoptériste 5: 1-88.

Erwin TL, Kavanaugh DH (1981) Systematics and zoogeography of Bembidion Latreille: I. The carlhi and erasum groups of western North America (Coleoptera: Carabidae, Bembidiini). Entomologica Scandinavica, Supplement 15: 33-72.

Kavanaugh DH (1979) Studies on the Nebriini (Coleoptera: Carabidae), III. New Nearctic Nebria species and subspecies, nomenclatural notes, and lectotype designations. Proceedings of the California Academy of Sciences 42: 87-133.

Kavanaugh DH, Erwin TL (1991) The tribe Cicindini Bänninger (Coleoptera: Carabidae): Comparative morphology, natural history, and reclassification. Proceeding of the Entomological Society of Washington 93(2): 356-389.

Kirby W (1825) A description of some insects which appear to exemplify Mr. William S. MacLeay's doctrine of affinity and analogy. Transactions of the Linnean Society of London 14: 93-110. doi: 10.1111/j.1095-8339.1823.tb00081.x

Lenko K (1972) Pseudomorpha laevissma, um carabideo mirmecofilo (Coleoptera: Carabidae). Studia Entomologica 15: 439-444.

Liebherr JK, Kavanaugh DH (1985) Ovoviviparity in carabid beetles of the genus Pseudomorpha (Insecta: Coleoptera). Journal of Natural History 19: 1079-1086. doi: 10.1080/00222938500770681

Moore BP (1964) Australian larval Carabidae of the subfamilies Broscinae, Psydrinase, and Pseudomorphinae (Coleoptera). Pacific Insects 6: 242-246. 
Moore BP (1974) The larval habits of two species of Sphallomorpha Westwood (Coleoptera: Carabidae: Pseudomorphinae). Journal of the Australian Entomological Society 13: 179-183. doi: 10.1111/j.1440-6055.1974.tb02171.x

Moore BP (1983) A guide to the beetles of south-eastern Australia, fasc. 5: 69-84. Australian Entomological Press, Greenwich.

Newman E (1842) List of Insects collected at Port Philipp, South Australia, by Edmund Thomas Higgins, Esq. Entomologist 23: 361-369.

Notman H (1925) A review of the beetle family Pseudomorphidae, and a suggestion for a rearrangement of the Adephaga, with descriptions of a new genus and new species. Proceedings of the United States National Museum 67(14): 1-34.

Ober KA, Maddison DR (2008) Phylogenetic relationships of tribes within Harpalinae (Coleoptera: Carabidae) as inferred from 28S ribosomal DNA and the wingless gene. Journal of Insect Science 8(63): 1-32.

Ogueta E (1967) Las especies argentinas de la subfamilia Pseudomorphinae G. Horn, 1881. Acta Zoológica Lilloana 23: 217-232.

\section{Appendix I}

Institutions and personnel who loaned specimens for this revision.

BMNH Maxwell V. L. Barclay, Curator and Collection Manager, Entomology: Coleoptera \& Hemiptera, Department of Life Sciences, Natural History Museum, London SW7 5BD

SEAG S. Brule, J.L. Giuglaris, The Entomological Society Antilles-Guyane, stephanebrule973@hotmail.fr

\section{Appendix 2}

Errata: In Erwin and Geraci (2008), Figure captions 13 and 14 are reversed. Fig 13 is Notopseudomorpha sp., Costa Rica, and fig. 14 is Pseudomorpha excrucians Kirby. 


\section{Appendix 3}

Table I. Measurements and ratios for Guyanemorpha spectabilis sp. n., all measurements are in millimeters.

\begin{tabular}{|c|c|c|c|c|c|}
\hline \multicolumn{6}{|c|}{ Total length (sbl) } \\
\hline \multicolumn{3}{|c|}{ Males } & \multicolumn{3}{|c|}{ Females } \\
\hline $\mathrm{N}$ & Range & Mean & $\mathrm{N}$ & Range & Mean \\
\hline 2 & $12.079-12.135$ & 12.107 & 2 & $11.053-12.185$ & 11.844 \\
\hline \multicolumn{6}{|c|}{ Maximum width (tw) } \\
\hline \multicolumn{3}{|c|}{ Males } & \multicolumn{3}{|c|}{ Females } \\
\hline $\mathrm{N}$ & Range & Mean & $\mathrm{N}$ & Range & Mean \\
\hline 2 & $6.356-6.378$ & 6.367 & 2 & $6.41-6.864$ & 6.637 \\
\hline \multicolumn{6}{|c|}{ W of head/w of left elytron } \\
\hline \multicolumn{3}{|c|}{ Males } & \multicolumn{3}{|c|}{ Females } \\
\hline $\mathrm{N}$ & Range & Mean & $\mathrm{N}$ & Range & Mean \\
\hline 2 & $1.041-1.069$ & 1.055 & 2 & $0.980-0.991$ & 0.986 \\
\hline \multicolumn{6}{|c|}{ Pronotum: width (at widest part)/length } \\
\hline \multicolumn{3}{|c|}{ Males } & \multicolumn{3}{|c|}{ Females } \\
\hline $\mathrm{N}$ & Range & Mean & $\mathrm{N}$ & Range & Mean \\
\hline 2 & $2.193-2.220$ & 2.207 & 2 & $2.253-2.327$ & 2.29 \\
\hline \multicolumn{6}{|c|}{ Length of pronotum / length of head } \\
\hline \multicolumn{3}{|c|}{ Males } & \multicolumn{3}{|c|}{ Females } \\
\hline $\mathrm{N}$ & Range & Mean & $\mathrm{N}$ & Range & Mean \\
\hline 2 & $1.959-2.027$ & 1.993 & 2 & $2.040-2.285$ & 2.163 \\
\hline \multicolumn{6}{|c|}{ Apparent body length (abl) } \\
\hline \multicolumn{3}{|c|}{ Males } & \multicolumn{3}{|c|}{ Females } \\
\hline $\mathrm{N}$ & Range & Mean & $\mathrm{N}$ & Range & Mean \\
\hline 2 & $13.510-14.480$ & 13.995 & 2 & $13.180-14.180$ & 13.68 \\
\hline \multicolumn{6}{|c|}{ Pre-ocular length / eye length } \\
\hline \multicolumn{3}{|c|}{ Males } & \multicolumn{3}{|c|}{ Females } \\
\hline $\mathrm{N}$ & Range & Mean & $\mathrm{N}$ & Range & Mean \\
\hline 2 & $0.435-0.554$ & 0.494 & 2 & $0.520-0.551$ & 0.535 \\
\hline
\end{tabular}

